de Deuxchaisnes C. Pattern of Lyme arthritis in Europe: report of 14 cases. Ann Rheum Dis 1988; 47: 164-5.

2 Herzer P, Wilske B, Preac-Mursic V, Schierz G, Schattenkirchner M, Zöllner N. Lyme arthritis: clinical features, serological and radiological findings of cases in Germany. Klin Wochenschr 1986; 64: 206-15.

3 Herzer P, Wilske B. Lyme arthritis in Germany. Zentralbl Bakteriol Mikrobiol Hyg [A] 1986; 263: 268-74.

4 Herzer P. Lyme borreliosis in Europe: an analysis of joint manifestations. Proceedings of the plenary lectures and round table discussions, XIth European Congress of Rheumatology. Athens: Tagas, 1987: 242-5.

5 Hollström E. Successful treatment of erythema chronicum migrans Afzelii. Acta Derm Venereol (Stockh) 1951; 31: 235-43.

6 Muhlemann M F, Wright D J M. Emerging pattern of Lyme disease in the United Kingdom and Irish Republic. Lancet 1987; i: $260-2$.

7 Stanek G, Wewalka G, Groh V, Neumann R, Kristoferitsch W. Differences between Lyme disease and European arthropodborne borrelia infections. Lancet 1985; i: 401 .

8 Steere A C, Malawista S E, Hardin J A, Ruddy S, Askenase P W, Andiman W A. Erythema chronicum migrans and Lyme arthritis: the enlarging clinical spectrum. Ann Intern Med 1977; 86: 685-98.

9 Herzer P. Die Klinik der Lyme-Arthritis: Unterschiedliche Befallsmuster und Krankheitsverläufe. $Z$ Rheumatol 1986; 45: 175 .

10 Steere A C, Schoen R T, Taylor E. The clinical evolution of Lyme arthritis. Ann Intern Med 1987; 107: 725-31.

\section{Natural killer cell function in ankylosing spondylitis}

SIR, Natural killer (NK) function has been assessed in several studies in rheumatoid arthritis, ${ }^{1}$ but rarely in ankylosing spondylitis (AS).

Recently, many reports have argued for the responsibility of bacterial agents in the development of AS. Anomalies of the immune response against bacterial antigens could favour the occurrence and development of AS. ${ }^{2}$

The purpose of this study was to evaluate NK function in patients with AS.

NK cells, in addition to their role in immunological antitumoral surveillance, ${ }^{3}$ appear to be implicated in anti-infectious and antibacterial defences. This is illustrated by the Chédiak-Higashi syndrome, characterised by functional deficiencies of NK activity with a normal number of NK cells, and the occurrence of severe bacterial infections. $^{45}$

Twenty eight patients (23 male, five female) with definite AS were investigated: mean age 39.5 (SD 5.2) years, $21^{-}$were HLA-B27 positive, and 17 were receiving non-steroidal anti-inflammatory drugs (NSAIDs) at the time of investigation. Duration of the disease was less than five years in nine cases and more than 10 years in 12 (mean (SD) $9.4(2 \cdot 8)$ years).

Lymphomonocytes were isolated from peripheral venous blood using a Ficoll-Hypaque density centrifugation gradient.

NK function was investigated, firstly, by spontaneous cytotoxicity against a $\mathrm{K} 562$ cell line preincubated with a fluorogenic substrate, and evaluated by a flow cytometric assay as described by McGinnes et $a l^{\circ}$ and, secondly, by the use of a Leu-7 (HNK-1) monoclonal antibody (Becton-Dickinson) that recognises NK lymphocyt subpopulation. ${ }^{78}$ Nineteen healthy blood donors reps? resented the control group; all were HLA-B27 negativeo

Monoclonal fixation of OKT3, OKT4, OKT8 (Orthछ Diagnostics), and several inflammatory parameter (erythrocyte sedimentation rate (ESR), $\beta_{2}$ microglobulin serum $\operatorname{IgA}$ concentration) were investigated on the same blood samples.

Statistical comparison of the different groups or sub $\overrightarrow{-}$ groups of patients was obtained by a Mann-Whitney test:and correlation between different parameters was sought with a linear regression test and $\mathbf{R}^{2}$ coefficient evaluation

We found no difference in NK cell activity eithef between patients with AS and controls (as in previous research with a ${ }^{51} \mathrm{Cr}$ release assay ${ }^{9-11}$ ), or between B27 positive and B27 negative patients with AS. Similarly, we found no statistical difference in the number of Leu- $\widehat{C}$ bearing cells between B27 positive and B27 negative patients with AS. Thus this study provides no evidence foํ NK function control by the B27 gene.

Moreover, no correlation was found between NKS activity and any of the other parameters investigate $\Phi$ (ESR, $\beta_{2}$ microglobulin, IgA, Leu-7, OKT3, OKT4尽 OKT8, T4/T8 ratio).

NK activity was significantly decreased $(p=0.006) \stackrel{\mathbb{C}}{\text { (1) }}$ however, in patients with AS receiving NSAID treatmenţ compared with non-treated patients. As has been showioniro vitro $^{12}$ and in vivo ${ }^{13-15}$ NSAIDs tend to enhance NK celpo activity. Thus the decrease observed in this study could due to activity of the disease itself rather than to a direct effect of NSAIDs upon cell activity. This has already been suggested by Vinje $e t$ al, who found a negative correlatiom between NK activity and $C$ reactive protein. ${ }^{11}$

Such a reduction in NK activity could be either evidence of an inflammatory reaction leading to hyperproduction oळ prostaglandins (that decrease NK activity) or, alterna tively, a pathogenetic factor contributing to persistence o bacterial antigens according to the current hypothesis of. the aetiology of the disease.

Service de Rhumatologie and the Centre de Transfusion Sanguine, Centre Hospitalier Universitaire, F 25030, Besancon,

Cedex, France

\section{References}

1 Faure G, Bene M C, Tamisier J N, Thomas P. Monoclonain antibody (HNK 1 Leu 7) defined lymphoid cells in the blood oP rheumatoid arthritis patients. Arthritis Rheum 1983; 26: 1173-5N

2 Wendling D. Immunopathogénie des spondyloarthropathies Semaine des Hopitaux de Paris 1987; 63: 2240-6.

3 Herberman R B. NK cells and other natural effector cells. New York: Academic Press, 1982.

4 Katz P, Zaytoun A M, Fauci A S. Deficiency of active naturaf killer cells in the Chédiak-Higashi syndrome: localization of the defect using a single cell cytotoxicity assay. J Clin Invest $1982 \%$ 69: $1231-8$

5 Roder J C, Haliotis T, Klein M, et al. A new immunodeficienc $\bar{D}$ disorder in humans involving NK cells. Nature 1980; 284: 553-5: 6 McGinnes K, Chapman G, Marks R, Penny R. A fluorescenc\& 
NK assay using flow cytometry. J Immunol Methods 1986; 86: $7-15$.

7 Abo T, Balch C M. A differentiation antigen of human NK and $K$ cells identified by a monoclonal antibody (HNK-1). $J$ Immunol 1981; 127: 1024-9.

8 Lanier L L, Le A M, Phillips J H, Warner N L, Babcock G F. Subpopulations of human natural killer cells defined by expression of the Leu-7 (HNK-1) and Leu-11 (NK-15) antigens. $J$ Immunol 1983; 131: 1789-96.

9 Armstrong R D, Panayi G S. Natural killer cell activity in inflammatory joint disease. Clin Rheumatol 1983; 2: 243-9.

10 Thoen J, Forre O, Pahle J. NK cells in rheumatoid arthritis and seronegative arthritis [Abstract]. Clin Exp Rheumatol 1987; 5 (suppl 2): 133.

11 Vinje O, Forre O, Degre M, Moller P. Natural killer cell activity of peripheral blood lymphocytes from patients with Bechterew's syndrome (ankylosing spondylitis). Scand $J$ Rheumatol 1984; 13: 297-302.

12 Combe B, Pope R, Darnell B, Talal N. Modulation of natural killer cell activity in the rheumatoid joint and peripheral blood. Scand J Immunol 1984; 20: 551-8.

13 Gonik B, Loo L S, Bigelow R, Kohl S. Influence of naproxen therapy on natural killer cytotoxicity and antibody-dependent cellular cytotoxicity against cells infected with herpes simplex virus. J Reprod Med 1984; 29: 722-6.

14 Kohl S, Jansen D M, Loo L S. Indomethacin enhancement of human natural killer cytotoxicity to herpes simplex virus infected cells in vitro and in vivo. Prostaglandins Leukotrienes Med 1982; 9: 159-66.

15 Lala P K, Parhar R S, Singh P. Indomethacin therapy abrogates the prostaglandin-mediated suppression of natural killer activity in tumor-bearing mice and prevents tumor metastases. Cell Immunol 1986; 99: 108-18.

\section{Changing the class of NSAID in cases of hepatotoxicity}

SIR, Hepatic side effects with non-steroidal anti-inflammatory drugs (NSAIDs), especially with diclofenac, are rare. Subclinical biochemical abnormalities, however, such as increases in transaminases, serum alkaline phosphatase and glutamyl transferase levels, and acute hepatitis, have been reported. ${ }^{1-3}$ When NSAIDs are stopped disturbances generally resolve. The problem then is to determine whether another NSAID can be given and which one to choose.

A man of 44 with ankylosing spondylitis had been taking diclofenac $(200 \mathrm{mg} /$ day) for two months. On investigation his sedimentation rate was $100 \mathrm{~mm} / \mathrm{h}$, white cell count $9 \cdot 1 \times 10^{9} / \mathrm{l}$, eosinophils $8 \cdot 1 \times 10^{8} / \mathrm{l}$, IgE $563 \mathrm{mg} / 1$ (normal $<350$ ), serum alanine aminotransferase 9 IU/l (normal $<30$ ), serum aspartate aminotransferase $16 \mathrm{IU} / 1$ (normal $<45$ ), serum glutamyl transferase 82 IU/l (normal $<50$ ), serum alkaline phosphatase 144 IU/I (normal <90), 5 '-nucleotidase $7 \mathrm{IU} / \mathrm{l}$ (normal $<5$ ), total serum bilirubin $5 \mu \mathrm{mol} / \mathrm{l}$, prothrombin $75 \%$, amylase $20 \mathrm{IU} / \mathrm{l}$ (normal $<70)$. Hepatitis B surface antigen, anti-hepatitis B core antibodies, hepatitis A IgM, cytomegalovirus antibodies, antinuclear and antimitochondrial antibodies were absent. Ultrasonography, tomodensitometry, and cholecystography were normal. Treatment with diclofenac was stopped. Serum liver function tests, IgE concentration, and eosinophils returned to normal in 10 days. Treatment with ketoprofen $(150 \mathrm{mg} /$ day $)$ was started. Three months later biochemical liver tests were normal. Diclofenac was the most likely cause of the hepatic abnormalities according to imputability criteria ${ }^{4}$ as the patient had no history of hepatic disease and was not alcoholic, there was no sign of a viral hepatitis or of biliary tract obstruction, diclofenac was the only drug given, disturbances of serum liver function tests normalised after diclofenac was withdrawn. High levels of eosinophils and IgE suggest an immunoallergic mechanism.

Similar cases of patients developing abnormalities of serum liver function tests without clinical symptoms have also been reported, ${ }^{5}$ and it is advisable to stop the drug. If NSAIDs are still required the same drug should be avoided as illustrated by a case of relapsing hepatitis in a patient rechallenged with diclofenac. ${ }^{3}$ NSAIDs of the same chemical class should also not be given, as demonstrated by a case of cross hepatoxicity between two propionic acid derivatives: naproxen and fenoprofen. ${ }^{6}$ We suggest an NSAID of another chemical class be used. Further studies are necessary to confirm our hypothesis that changing to an NSAID of a different chemical class resolves the disturbances of hepatic toxicity and does not produce new features of liver damage.

Laboratoire de Thérapeutique,

G LLORCA UFR Lyon-Nord,

J P LARBRE

8 Avenue Rockefeller, 69373 Lyon Cedex 08, Ph COLLET A RaVAult France

Service de Rhumatologie,

E LEJEUNE Hôpital des Charpennes, 27 Grand Rue des Charpennes, 69603 Villeurbanne Cedex,

France

\section{References}

1 Babany G, Pessayre D, Benhamou J P. Hépatite au diclofénac. Gastroenterol Clin Biol 1983; 7: 316.

2 Deshayes P, Leloet X, Bercoff E, Fouin-Fortunet H. Hépatite au diclofénac. Une observation. Presse Med 1984; 13: 1847.

3 Dunk A A, Walt R P, Jenkins W J, Sherlock S S. Diclofenac hepatitis. Br Med J 1982; 284: 1605-6.

4 Begaud B, Evreux J C, Jouglard J, Lagier G. Unexpected or toxic drug reaction assessment (imputation). Actualization of the method used in France. Therapie 1985; 40: 115-8.

5 Ciccolunghi S N, Chaundri H A, Schubiger B I, Reddrop R. Report on a long term tolerability study of two years with diclofenac sodium. Scand J Rheumatol 1978; suppl 22: 86-96.

6 Andrejak M, Davion T, Gineston J L, Capron J P. Cross hepatoxicity between non-steroidal anti-inflammatory drugs. $\mathrm{Br}$ Med J 1987; 295: 180-1. 